\title{
Chapter 8 \\ The Jews of Shanghai under Japanese Rule
}

\section{The Jewish Community Prior to the Japanese Occupation}

The largest Jewish community in East Asia in the mid-1930's resided in Shanghai, the hub of China's international trade, where the largest concentration of foreign residents in general lived and worked. This was partly due to the existence of the International Settlement quarter that was created in 1842 , under the protection of eleven foreign powers and administered by a municipal council representing them. Formally, this settlement was under Chinese sovereignty, but in reality the settlement's foreign residents were not under the authority of the Chinese police or other local governmental institutions, and enjoyed the protection of the consuls of France, Britain, the United States, Japan, and Russia. There was also a French Concession where some Jews found refuge, and where effective Chinese sovereignty was also non-existent. Additionally, there was the Hongkew zone of Shanghai, which for decades had been part of the International Settlement, but which came under direct Japanese rule in August 1937. Finally there was the rest of Shanghai, a city of 4.5 million inhabitants administered by a pro-Japanese puppet Chinese government but in reality controlled by Japan. The special character of the foreign settlement and the possibilities of finding both refuge and business opportunities there attracted many foreigners, among them Jews.

The first wave of Jewish settlers who established the Shanghai Jewish community arrived in the middle of the nineteenth century. Some came from Iraq and Persia via India. Many had British passports, and soon a number of families stood out for their wealth and communal leadership. Among them were the Sassoon, Kadoorie, Hardoon, Elias, Gubai, and other families. In 1902 the Ohel Rachel (Rachel's Tent) synagogue was inaugurated, 
named after the late wife of Sir Jacob Sassoon. The Hardoon family built the Beit Aharon (The House of Aaron) synagogue, named after Aaron Hardoon (1851-1931). The Zionist movement had an active branch there, and its publication, The Israel Messenger, is a highly credible source for the history of this community as it grew bigger and richer. On the eve of the First World War, it numbered over a thousand individuals.

The second wave arrived after the Bolshevik Revolution in 1917, in the form of several thousand refugees from Russia, among them hundreds of Jews. Shanghai was convenient for those who sought haven because there was no need for entry and residence permits, and there was also a supportive Jewish community already there and ready to help. In addition to the Jews there were also hundreds of White Russian émigrés who brought with them antisemitic doctrines and literature which placed the blame for the Russian Revolution squarely on the Jews. The Jews were also accused of the murder of the Tsar and his family, and all of the social and political ills and upheaval and turmoil that followed the 1917 Revolution were attributed to them as well. The Jews already residing in Shanghai, many of them originating in Central and Eastern Europe, were not enthusiastic about the growth of the Russian Jewish community, which on the eve of the Second World War numbered some five to eight thousand people, a huge increase from the several hundred who were present in the 1920's. Their spiritual head was Rabbi Meir Ashkenazi, a Lubavitcher Chassid who came from Vladivostok by way of Harbin. Many of this new wave of Russian Jews came from Harbin, Mukden, and Dairen after Manchuria was occupied by the Japanese in 1931. They preferred living in a city where Western culture and a greater sense of law and order prevailed to remaining in the Japanese-occupied areas. The Russian Jewish immigrants at once set out to establish their own communal institutions and built an old-age home that served meals for the needy, which by then meant some 400 people. They also established their own burial society, religious schools, and a charitable fund for the needy.

In 1931 an organization called the Shanghai Ashkenazi Relief Association (SACRA) was established. It claimed to represent the entire Jewish community in that city, but in reality it was distinctly separate from the old-time wealthier Sephardic community. In 1937, on the eve of the second Sino-Japanese War, SACRA won recognition from the Chinese nationalist government. Parallel to this body there also existed the Judische Gemeinde, the umbrella organization of Jews who came from German-speaking Europe. It was this organization that began to deal with the growing number 
of Jewish refugees from Nazi Germany after the rise of Hitler to power in 1933.

\section{After Shanghai's Occupation by Japan}

Shanghai's occupation by Japan in August 1937 left the legal status of the foreign settlements intact: the Foreign Settlement and the French Concession retained their autonomous status under the protection of the Western powers and the Soviet Union. Since Japan did not want to provoke the Western powers and the Soviet Union, there was no attempt by the Japanese to harm Central European, Russian, or Sephardi Jews in Shanghai, especially those who were either Soviet citizens or stateless persons under Soviet protection. Japan's basic policy toward the foreigners in Shanghai was to treat them fairly while maintaining close surveillance over their activities, mainly through the control of their communal organizations.

The growth of the German Jewish community in Shanghai can be traced to the events of 1934, a year after Hitler's ascent to power, when a small number of German Jewish physicians arrived in China and found work in Shanghai and other cities that were yearning for medical doctors. Some traveled to China via the Soviet Union on the Trans-Siberian Railway, continuing south from Manchuria. Others came directly by sea, sailing on board Japanese and Italian vessels, mostly those of the Italian Lloyd Triestino. The growing number of Jews arriving in Shanghai at this time can also be explained by the policy of the Gestapo, which encouraged Jewish emigration mainly from Austria, a policy led by the rising Nazi official Adolph Eichmann (1906-1962) and his aides.

Eichmann was at the time in charge of getting rid of the Jews of Austria. $\mathrm{He}$ and his associates met with foreign consuls in Vienna, including those of China and Japan, and encouraged them to issue visas to Austrian Jews. They also urged shipping companies to allocate additional places on their vessels to accommodate Jews, and to arrange for extra journeys. Another source of the Jews arriving in China were the visas issued by the Chinese Consul General in Vienna, He Feng Shan (1901-1997). The records of the Shanghai police show the arrival in 1938 of 1,374 Jewish refugees. A year later the number grew to 12,089, but in 1940 the figures declined to 1955 and in 1941 only 33 are listed. When Japan attacked America in December 1941, followed by Germany and Italy's declaration of war against America, this channel of travel shut down entirely. 
During the four years 1938-1941, 15,450 Jewish refugees arrived in Shanghai. They joined the existing community, and in early 1942 there was a total of 27,000 Jews in Shanghai, comprising about a third of all foreigners living there at the time. The majority resided in the Hongkew neighborhood in central Shanghai.

Since 1938, the organization that looked after the refugees had been the Committee for the Assistance of Jewish refugees in Shangahi, or the CFA. They provided help in finding housing, employment, schooling, and kindergartens for the refugees and their children and acted as mediators in the many conflicts that arose between the newly arrived refugees and the older, more established members of the Jewish community. Among the major donors to this body were Sir Victor Sassoon and Eli Kadoorie. American Jewish organizations such as the Joint Distribution Committee and HIAS also sent funds that in 1940 were estimated at half a million dollars. Some of the refugees also received funds from their family members living in the United States.

On the eve of the Pacific War, a number of Japanese officers, including the Jewish experts, understood that the wealthy Jews of Shanghai could be of use to Japan in implementing its new policy, the Greater East Asia Co-Prosperity Sphere. This was a rehash of similar ideas that were previously discussed about making use of the Jews of Manchuria in the late 1930's. In Shanghai there lived a number of very wealthy Jewish families with vast international business connections. Perhaps they could be mobilized to help Japan's economy, or at least to advance Japanese economic interest in the areas it occupied in China beginning in July 1937.

In May 1939, three Japanese officers met with Sir Victor Sassoon, recognized by all parties as the uncrowned leader of the Jewish community, to discuss the plight of the 12,000 Jewish refugees in the Shanghai area. One of them was Colonel Yasue, the second Captain Inuzoka, and the third Japan's consul in Shanghai, Ishiguro Shiro. A meeting was required as the Japanese officials and the Jewish leaders of Shanghai were becoming increasingly concerned over the rising tide of German, Austrian, and Czech Jewish refugees. The issue became more acute with the growing flow of refugees, partly because various foreign consuls residing in Shanghai recommended to their governments, as was their right to do during this era of the International Settlement and the French Concession, that it would be wise to halt the flow of Jews to that city. These recommendations were not to the taste of the Japanese authorities, who did not want Japan to be tainted with the negative image of a country that is oblivious to the plight of refugees. As usual, they wondered how the refusal to accept refugees would be seen 
by American Jews, who were perceived to have vast influence over public opinion in America through their control of the media in that country. By 1939 and 1940 several ideas began to be discussed in Tokyo, among them the notion that Japan could concentrate the Jews into a special section in Shanghai and make it into a Jewish puppet state, similar to Manchukuo. It was also assumed that this would make it easier to control the Jews of Shanghai, with the help of the existing local Jewish organizations. Since the Japanese navy was responsible for Shanghai, it did not come as a surprise that Captain Inuzuka was asked to become involved. His first step was to establish, in January 1940, a special bureau for Jewish affairs.

\section{After Pearl Harbor}

On December 7, 1941, the Japanese attacked the US Navy's Pearl Harbor in Hawaii, and Japan entered into Germany and Italy's war against the Western democracies. The Japanese army now occupied the International Settlement and the French Concession, ending the international control that had existed there since 1842. A day after Pearl Harbor, Inuzuka seized the office of Victor Sassoon and turned it into his headquarters. But at this stage there were no indications that the Shanghai Jews were to be subjected to special treatment. Indeed, until 1943 there was little anti-Jewish discrimination. The main concern of the Shanghai Jewish community was how to handle the refugees in that city, to whom were now added several hundred who arrived from Kobe, having gotten their transit visas to Japan by the Japanese Consul in Kaunas, Sugihara Chiune. They had been unable to leave Japan for Curacao or other destinations before Pearl Harbor, and were transferred by Japan from Kobe to Shanghai after the war against the United States began. As we shall see later, the movement from Kobe to Shanghai started in early 1941, and was paid for by the Joint Distribution Committee in New York at the specific request of the Kobe Jewish community. Among the refugees was the entire Mir Yeshiva, consisting of several hundred students and teachers. The Judische Gemeinde assisted the local community by feeding the refugees, using funds that continued to come from the United States through the Joint Distribution Committee until 1943, apparently with Japan's knowledge and encouragement. The funds were sent through neutral Switzerland. The representative of the JDC in Shanghai, Laura Margolis, maintained cordial ties with Captain Inuzuka and operated freely until she was interned as an enemy alien in February 1943 and repatriated to the United States in September 1943. 
Until the summer of 1942, there was no attempt to harm the Jews in Shanghai. Quite the contrary: the vast literature that exists on the Shanghai Jewish community during the war describes in great detail the ongoing and endless internal struggles and constant fighting among the various Jewish organizations over such issues as financial aid to refugees, school curriculae, the style of prayers in synagogues, and the distribution of funds that came from the United States. In order to qualify for aid, one had to register with the Judische Gemeinde, and two thirds of the community did so. In May of 1942, the Japanese occupation authorities demanded that all Jews register with the government and list their residences and occupations. A document from that time, a 1941 census, shows that among the Jewish refugees in Shanghai there were 220 physicians, 180 dentists, 120 nurses, 22 milliners, 130 engineers, 1100 merchants, 150 chefs, 140 people in the meat trade, and 100 chauffeurs. Japanese representatives began to participate in meetings of the local Jewish organizations to exercise control, demonstrate the government's presence, and ensure that there would be no manifestations smacking of anti-Japanese sedition, mainly in the Jewish publications that began to appear in Shanghai. They also aimed to ensure that there would be absolutely no contact between the Jews of Shanghai and enemy countries, mainly the United States and Britain. In order to facilitate control over the Shanghai Jewish communal organizations, the Japanese authorities decided in May 1943 to place the Judische Gemeinde and the Ashkenazi social welfare body (SACRA) under the leadership of Dr. Abraham Cohen, a Romanian Jew who studied medicine in Japan and spoke fluent Japanese. He was the rare exception - a Jewish leader fluent in Japanese.

\section{German Extermination Plans}

The relative calm which the Shanghai Jews were enjoying was about to end. From testimonies gathered after the war, it appears that the German government pressed Japan to take measures aimed at dealing with the Jews under its control. Fritz Wiedemann (1891-1970), who served as the German Consul General in Tianjin but was in fact the key German intelligence officer in China between 1941 and 1945, testified in 1951 that he had no doubt that German pressure brought about a change in Japan's previous policy toward the Shanghai Jewish community. His testimony was supported by a Japanese naval officer by the name of Takeshima, who had served as an intelligence officer in Shanghai. In July of 1942, the ardent Nazi Gestapo Colonel Josef Meisinger (1899-1947) arrived in Shanghai. ${ }^{2}$ 
In the 1930's, prior to his arrival in Shanghai, Meisinger had been head of the Nazi office dealing with matters relating to abortions and homosexuality. After the outbreak of the war he served in Poland, where he earned the sobriquet "the Warsaw Butcher" for his actions in organizing the Warsaw ghetto and mainly for his responsibility for the deaths of thousands of Jews in the Polish capital. In 1941 he was appointed to the German Embassy in Tokyo as police attaché. He was, in fact, the senior representative of Germany's Gestapo in Japan, seeking enemies of Nazi Germany within the German community of Tokyo. He also served as the liaison between the Gestapo and the Japanese intelligence services. In Tokyo he befriended the Soviet spy Richard Sorge (1899-1944) and became a major source of information for Sorge (who was captured by Japanese counter-intelligence agencies in October 1941 and executed three years later). In 1942 Meisinger was sent to Shanghai, where he took upon himself the task of dealing with the Jews of that city. He was assisted by an SS officer called Hans Neiman who at the end of the war was responsible for the Bergen-Belsen concentration camp. Another aide was an officer named Adolph Pottkamer, who was in Shanghai in the guise of commercial attaché at the German embassy in Tokyo.

In early 1942, the Japanese naval authorities responsible for the Shanghai area had already come to the conclusion that Japan's control over foreigners in general and Jews in particular would have to be tightened, and that perhaps it would be useful and easier to concentrate some 20,000 Jews in one neighborhood and eventually get rid of them (and the non-Jewish Russians) altogether. The German officers probably heard from the Japanese navy that they were wondering how to better control the foreigners in Shanghai.

From sources within the Japanese consulate in Shanghai, some Jewish leaders learned as early as August 1942 that Meisinger had proposed to a number of Japanese officers that they begin to act against the Jews in the spirit of the Final Solution. He suggested a number of concrete courses of action. One was to send those Jews who were once German nationals to Japan to work as forced laborers for the Japanese war effort. The second was to use Jews as guinea pigs for experiments on human beings. The third and most lethal was to put thousands of Jews aboard cargo ships and either starve them to death on board or sink them in the China Sea. Another remote idea was to transfer the Jews to Nazi occupied Europe where they would be exterminated. But as a first step, and prior to taking drastic measures agains the Jews, they should be concentrated into one area. 
The experts thought it would be easy to round up all the Jews on the eve of the Jewish New Year, since many of them would be in synagogues.

Among those present at the discussions with the Germans on this topic was the Japanese Vice Consul Shibata Mitsugu, who decided to alert a number of Jewish communal leaders to the plot being hatched by the Nazis. One of those leaders, Dr. Abraham Cohen, had already heard of the plan from his own sources, including some Japanese officers whom he had befriended. He met with a Japanese officer, Kubota Tetsuma, who promised to see what could be done to thwart the plot. Shortly thereafter Meisinger's ideas were leaked to a local Chinese-language newspaper and published. This caused great deal of anger in the Japanese navy headquarters. The navy resented the publicity, as they were not sure whether the German method was the right way to go about resolving the "Jewish Question" in Shanghai.

It is not clear if the Japanese authorities were indeed interested in undertaking such radical measures against the Jews, which could have meant the arrest, detention, and even extermination of some 27,000 people, most of them of European origin. It can be assumed that they did not want to harm the wealthy Sephardi Jews who held British or American passports and who were already interned in detention camps until the end of the war. Russian Jews were automatically excluded, so as not to harm the delicate relations with the Soviet Union.

The Japanese authorities were furious over the leak. Vice-Consul Shibata was arrested, as were some leaders of the Jewish community. They were all released after a few days, but the Japanese authorities were probably terrified by how easily this German-inspired plan could be leaked and thus foiled. Shibata was detained for several months, sent back to Japan, and then dismissed from the Japanese Foreign Service. It was now evident that some Japanese naval officers as well as Japanese diplomats did not view with favor the idea of Japan doing the bidding of the Nazis regarding the Jews. This too had to be taken into consideration when the time came to make a decision.

\section{The Creation of the Hongkew Ghetto}

Over the course of late 1942 and early 1943, Meisinger continued to pressure the Japanese authorities in Shanghai to take action against the Jews, and they finally chose what they may have considered the lesser evil: they decided to set up a Jewish ghetto in Shanghai, which was politely called a "designated area." The reason for choosing this option probably had to 
do with their reluctance to follow the Nazis in their anti-Jewish policy of extermination, although the Japanese were not aware of the dimensions of the Holocaust and the extermination already taking place in Auschwitz, Treblinka, Majdanek, and other death camps. They may have feared that exterminating some 20,000 Jews of European origin would create furor in the West. They also did not see much sense in killing the wealthy Jewish families of Shanghai, who might in the future be useful for Japan's economic plans. Above all, they recoiled from killing scores of Jews who held British and American citizenships, fearing terrible retribution after the war in case Japan lost. The decision was made in early 1943 and was based on prior Japanese thinking, which had considered the possibility of a Jewish ghetto in Shanghai. By then, the tide of the Pacific war had begun to turn against Japan. However, there is no evidencd that the turning of the tide in any way influenced Japanese thinking regarding the "designated area."

On February 18, 1943, an ordinance was issued relating only to the approximately 14,000 stateless refugees who had come to Shanghai after September 1939. They were ordered to move to a "designated area for stateless refugees" adjacent to the international settlement Hongkew. The words ghetto and Jews were never mentioned, but the intention was quite clear. Those affected were stateless Jewish refugees from Germany, Austria, Czechoslovakia, Hungary, Poland, Latvia, Lithuania, and Estonia. Russian Jews were totally excluded from this ordinance. Several Jews who held Polish passports requested that they be treated as Russians, claiming that they had come from areas occupied by the Russians in 1939. The Japanese consul Kubota met with the heads of the Jewish community and asked for their cooperation in moving the designated groups of Jews to the ghetto. They had no choice but to comply. Within a few weeks some five thousand Jews were moved to Hongkew, including three hundred Mir yeshiva students who continued their studies in a building they renamed "Beit Aharon." It can be conjectured that Meisinger and his assistants were involved in this move, but the implementation was totally in the hands of the local Japanese authorities.

The Japanese officer responsible for the ghetto was Goya Kano, who had previously worked in the Japanese office responsible for stateless refugees. He was mainly in charge of issuing entry and exit permits to the ghetto and had four Jews on his staff. He was apparently a somewhat eccentric individual, who liked to call himself the King of the Jews. Many who survived their internment in the ghetto recalled him as a moody person and noted that they behaved towards him accordingly. Some thought he was a psychopath. 
Unlike the Jewish ghettos in Eastern Europe, the Shanghai ghetto was not that difficult to exit or enter during the two years and four months of its existence. One witness, Yosef Tekoa (1925-1991), future Israeli diplomat, Israeli ambassador to the Soviet Union and the United Nations, and president of Ben-Gurion University of the Negev, remembered no difficulty entering and leaving the Hongkew ghetto. ${ }^{3}$ Life for the five thousand Jews crowded into Hongkew was harsh-they lived in cramped quarters, few had income, and food was scarce-but they were not physically molested or harmed. They had to endure chilly winters and hot and humid summers. A number of Jewish newspapers, mainly in German, were published in the ghetto in those years. Not involved in the ghetto, the Russian Jews who had established a social club in 1931 maintained it even after Japan occupied Shanghai and turned it into an officers' club. The Russian Jews were undeterred and continued their club from the local Masonic chapter and in 1943 numbered some 450 people among its members.

Responsibility for maintaining law and order in the ghetto was given to the Jews themselves. Starting at the end of 1943 the Japanese once again allowed American Jewish organizations to send funds to China even though the United States was an enemy country. The Joint Distribution Committee resumed sending money through Switzerland. A hundred thousand Swiss Francs arrived from Switzerland in September 1943 through the channels of the International Red Cross, thereby alleviating the hunger of the Jews inside the ghetto. The transfer of funds was made possible by pressure exerted on the American State Department by the Union of Orthodox Rabbis in America. Most of the Jews in the ghetto were unemployed, and the prospects of finding employment, even outside the barbed wire wall that surrounded the ghetto, were virtually non-existent. Apparently some two thousand Jews died during the Japanese occupation of Shanghai, most of them from illnesses or old age. There is no evidence of executions or torture of Jews.

Those Jews in Shanghai who were not herded into the ghetto carried on their lives to the best of their ability under the Japanese occupation. Tekoa continued to attend the French university, his brother an American college whose gates were not closed by the Japanese. Virtually all the testimonies on this topic from people who were in Shanghai during those days-and there are scores-as well as the official documents and reports of Japanese consular officials and military officers and navy and army commanders confirm that the Japanese had no intention of exterminating the Jews under their control, but did not wish to make their lives easy either. Most likely the 
main reason for their caution was the growing realization of the Japanese leadership beginning in early 1943 that Japan was going to be defeated. They may have thought of their own personal future, and did not want to add to their war crimes against Chinese civilians additional ones against Jews. The Jewish complex in Japan was still alive: what would Japan do if the Jews, given their vast influence over Western governments, the media, and public opinion, accused it of implementing a Nazi-style Final Solution? In any case, many Japanese officials realized that they were already being demonized by the United States as bloodthirsty barbarians who committed atrocities not only against Chinese civilians but also against American civilians and prisoners of war in the Philippines in early 1942, specifically by forcing them to participate in the Bataan Death March. They did not wish to add charges of antisemitism against them at the end of the war.

Furthermore, after 1943, there is no evidence that Germany was in any way pressing Japan to persecute Jews in Japan, China, or other territories under Japanese occupation aside from Indonesia. That may be ascribed to the lack of cooperation between Japan and Germany in many spheres despite the fact that they were formally allies. Japan had already refused Germany's pleas to attack Singapore in 1940, and though Germany wanted Japan to invade the Soviet Union when that power was on the verge of collapse in October 1941, Japan maintained strict neutrality with the Soviet Union until a week before it surrendered. Japan did not see itself as committed ideologically or in any other way to the German policy of exterminating the Jews. It can also be assumed that Germany never revealed to Japan the details of the Final Solution or the manner in which it was carried out in Europe.

In other cities in China and Manchuria, Jews were not physically or otherwise molested, and the hundreds of Jews who remained in Harbin, Mukden, and Tianjin during the war did not report any assaults on them. On the contrary, Japan allowed the Jews in those cities (apart from Hong Kong) to lead their lives as before and did not destroy communal institutions, impose financial levies, or compel men to do forced labor. And so, while millions of European Jews were exterminated in death camps in Poland and other locations, the Jews under the Japanese occupation in China were spared from a similar fate and the majority survived the war. It is still a matter of debate whether there was an official Japanese government policy of protecting the Jews under their control, or whether the decisions were left to local commanders to make. It may seem symbolic, but the only 31 Jews killed and approximately 250 wounded in Shanghai were 
the result of an American air raid on Hongkew on July 17, 1945, a month before Japan surrendered. The wounded were treated in the Jewish hospital in the ghetto, which was was manned by Jewish doctors and nurses. The American bombers had sought to destroy a Japanese broadcasting station in the foreign quarter and missed their target.

\section{Japan's Attitude toward the Jews in Other Parts of China ${ }^{4}$}

Since late 1937 Japan had controlled about a third of China, mainly its northeastern parts and the key cities along the coast. It would be reasonable to assume that in order to solidify its control over these parts of China it would seek to launch a propaganda campaign against the West, and that the campaign would include some antisemitic sentiments, as similar campaigns did in Japan itself. Since the Kuomintang forces, in addition to sporadically fighting the Japanese forces, were also battling the Chinese Communists, whose center was in the Yenan enclave. However, unlike in Japan, where authorities used anti-communist sentiments (which were closely related to antisemitic sentiments) to describe part of the country's struggle against the West and the Soviet Union, in the occupied Chinese territories the Japanese refrained from using antisemitic propaganda. In any case the connecting line drawn between communism and Judaism would have meant nothing to the Chinese, who knew virtually nothing about Jews and Judaism. The Japanese propagandists could theoretically have used the fact that Karl Marx was a converted Jew, and that many of the Bolshevik leaders in Russia were Jews, a fact noted by Chiang Kai-Shek during his three-month-long sojourn in Moscow in 1923. The Japanese could have pointed out the fact that a number of the Comintern emissaries in China in the 1920's were Jews, but they chose not to do so.

It seems plausible that Japan's Jewish experts noted and advised their superiors that anti-Jewish propaganda and antisemitism would not strike a chord with the Chinese intellectuals and middle class. True, a number of Chinese Nationalist army officers and many students lived in Germany in the late 1920's and early 1930's, but they did not spread antisemitic ideas upon their return to China. Some may have refrained from doing so after noting that in Mein Kampf Hitler had written that "it was incorrect to believe that a Negro or a Chinese could ever take part in German life." When Mein Kampf was translated to Chinese in 1936, the offensive sentence 
was deleted. There was one faction in the Nationalist Party that did admire some aspects of Nazism, the Blue Shirts group, and they published allegations in their publications that "Germany's largest banks, newspapers, and other commercial enterprises are almost all controlled by the Jews." However, even the New Life Movement, which did agree with some Nazi principles, basically ignored antisemitism.

It was also hard for the Japanese, even if they were willing to do so, to fault the Jews for many of China's ailments. There is nothing in Confucianism, Buddhism. or Taoism that could encourage hatred toward the Jews. Even Christian missionaries in China did not go out of their way to blame the Jews for killing Christ. In the few cases in which Jewish traders did compete with overseas Chinese traders in South East Asia, there is no evidence that the competition created antisemitic sentiments. The Jews were seen by and large as Europeans, and were not singled out or identified specifically as Jews. Like those in Japan, the Jews who lived in China never played any role in China's politics, media, academia, or arts. The Jews of China were mostly merchants, many of them involved with international firms. It would have been quite difficult to fault the Jews for the economic collapse of 1929 and the worldwide depression that followed. Therefore, those very few Jews who lived in China under the Japanese occupationwith the exception of those in Hong Kong and Shanghai-were spared the manifestations of antisemitism that could so easily have been encouraged by the Japanese occupation authorities. Even the Nazi party branches in China did not publicly engage in overt antisemitic acts. 